\title{
Gender and Governance of Global Value Chains: promoting rights of women workers
}

\begin{abstract}
Private governance channelled through social compliance programmes and gender initiatives of multinational companies (MNC) are ineffective in tackling gender discrimination in global value chains. The United Nations Guiding Principles on Business and Human Rights (UNGP) provide a public-private governance framework to address human rights globally, including gender equality. This paper asks whether the UNGP can provide a more effective governance framework for addressing women workers' rights in global value chains. It argues interlayered forms of governance (involving public, private and social actors) are critical to addressing gender discrimination and advancing a gendered approach to human rights due diligence.
\end{abstract}

\section{Introduction}

Global value chains, largely coordinated by multinational companies (MNC), have generated hundreds of millions of jobs in low income and emerging economies. Women occupy a significant proportion, and are the majority in some sectors such as garments and food processing (Barrientos 2014; ILO 2015; Posthuma and Rossi 2017). However, global sourcing across international borders involves high levels of competition between companies, seeking lower production costs which results in precarious jobs for many workers, as labour is the cost factor suppliers often squeeze under pressure from MNC purchasing practices (ILO 2017). This especially affects workers from discriminated groups based on gender, caste, race, religion, ethnicity, physical ability or sexual orientation. In particular, women are disproportionally affected by business activities (Human Rights Council 2019), Gender discrimination is endemic in global value chains (GVC), and women drawn in as a source of low-cost labour are concentrated in the more insecure and less protected jobs with low pay and poor conditions (Barrientos 2019). They often lack the ability to negotiate the terms and conditions of work with their employers, organise through independent trade unions or raise grievances.

Many MNC, including retailers, brands and some large intermediaries, have adopted voluntary codes of labour practice to ensure minimum labour standards. In many cases, these have been developed in response to pressure from civil society organisations (CSO), in particular trade unions and nongovernmental organisations (NGO). Voluntary codes form part of MNC private governance of global value chains, and have spawned a large social compliance industry. However, social auditing of codes has largely failed to pick up or address gender discrimination and harassment, and the quality of audits is often poor (BSR 2018a; Barrientos 2019). There is growing recognition of the limitations of social compliance to address labour rights.

Some MNC looking 'beyond compliance' have adopted gender initiatives to promote the rights of women workers in their value chains. They have 
broadened their GVC governance to include support for women in communities or in the factories and farms from which they source (Scott 2017). In many cases delivery also involves collaboration with civil society organisations (CSO). However, an analysis of selected MNC gender initiatives (examined below) found that many are fragmented. They rarely address or prevent the underlying drivers of gender discrimination, nor the business operations of buyers and suppliers that can compound women's precarious work in GVCs.

The United Nations Guidelines on Business and Human Rights (UNGP), endorsed by the Human Rights Council in 2011, provide a broader governance framework some MNC are adopting. The first UNGP pillar emphasises the importance of public governance in promoting human rights (i.e. states duty to protect), whilst the second pillar recognises the importance of private governance by companies (i.e. business responsibility to respect). The third UNGP pillar is the right to access to remedy by workers and remediation for business-related abuses. The UNGP apply to cross-borders operations and business relationships, in line with the transnational character of GVC. They set a global standard of expected conduct that exists above national laws and refers to internationally recognised human rights, including the International Bill of Human Rights and the International Labour Organisation (ILO) Declaration on Fundamental Principles and Rights at work. In contrast to 'tick box' social compliance, the UNGP require a comprehensive accountability system based on human rights due diligence. The aim is to understand the potential or real impacts of business operations on rights holders (such as workers and local communities), and to take responsibility for mitigating and providing remedy to people where they have been adversely affected and their rights have been abused.

However, the debate around the UNGP has only recently begun to actively address gender as an underlying dimension of abuse (Bourke-Martignoni and Umlas 2018). Gender-specific rights violations, such as sexual harassment and abuse, which are prevalent in many global value chains (Fair Wear 2018), have largely been neglected by proponents of the UNGP, and significantly underrepresented in the scrutiny of other international standards. Gender discrimination is deeply entrenched in the social norms prevailing in most societies, shaping the subordinate role of women in both paid work and unpaid reproductive work (Himmelweit 2000). Public and private governance have a key role to play, but are not necessarily sufficient to address deep societally embedded gender discrimination. Social governance, involving civil society organisations, can also provide a channel for raising grievances and addressing the rights of more vulnerable and precarious workers. However, social governance is often a 'grey area' whose role is insufficiently recognised in analysis of GVC and human rights policy. Moreover, many women's organisations that have championed and led efforts to tackle gender discrimination in political and social spheres have not been as actively engaged in labour rights issues in global value chains involving the private sector.

This paper asks whether the UNGP have the potential to provide a more effective governance framework for addressing women workers' rights and promoting gender equality in GVC? It analyses the role different dimensions of governance 
(public, private and social) can play in promoting more gender equitable human rights. It explores the concept of governance in a GVC context, which has until recently largely conflated social with private governance exercised by companies. It examines why private governance, through social compliance (codes and auditing) implemented by MNC, has failed to identify or address gender discrimination. It highlights the specific role social governance can play in contesting private governance of $\mathrm{MNC}$, and raising gender rights issues beyond the workplace. It advances a gender analysis of interlayered private, social and public governance in a value chain context, and assesses the combined roles these can play in promoting gender equality and rights of women workers, in line with internationally recognised human rights.

The paper explores the role of multi-stakeholder initiatives (MSI), using the UK Ethical Trading Initiative (ETI) as an example of inter-layered private and social governance involving companies, trade unions and NGO. ETI has an established and globally recognised voluntary standard, the ETI Base Code, based on nine ILO Conventions that proscribe internationally agreed labour standards. ETI's model and approach is collaborative - involving companies, trades unions and NGO in holding companies to account for their commitments and progress on these labour standards. Whereas this area of work was regarded previously by companies as part of their corporate social responsibility (CSR) the UNGP has provided ETI with an enhanced and more strategic framework to support companies in meeting their human rights due diligence responsibilities. There has been a growing body of legislation and regulation to increase requirements for companies to be more transparent and demonstrate human rights due diligence, and ETI has contributed to these efforts, also recognising the increasingly important role of governments to regulate the private sector and create a more level playing field at a time of increasing global value chain complexity and competition.

The paper draws on empirical findings from a study of the gender initiatives of 10 ETI member-companies to highlight the benefits and limitations of a private governance approach to promoting gender equality in GVC, even where NGOs are also involved.

It provides an example of a company in the Kenyan tea sector to examine the potential of interlayering of private and social with public governance to promote gender equality and workers' rights. This illustrates the role companies and civil society actors can play in addressing gender rights, where public governance also provides an enabling legislative environment. The paper argues the UNGP provide a useful framework with potential to address gender rights by linking public and private governance, with social governance more firmly anchored in its implementation. CSO (particularly women's rights NGO and experts) can highlight rights abuses experienced by women workers and support them in accessing remedy; challenge the business models of MNC that pressure suppliers and reinforce precarious work and gender discrimination; and multistakeholder initiatives such as the ETI can act as effective intermediaries within an interlayered private, social and public governance framework. 
The paper is organised as follows. Section 2 provides an analytical exploration of governance, examines the gender limitations of private governance, applied through social auditing of codes of labour practice. Section 3 examines the findings from an analysis of gender initiatives being supported by ten ETI companies in their global value chains. It highlights the example of the tea supplier, which has evolved an interlayered private, social and public governance similar to some Kenyan flower growers, an approach that appears more effective. Section 4 weighs up the potential for the UNGP framework to provide a framework for promoting gender equality in GVC involving interlayered public, private and social governance. Section 5 briefly concludes.

\section{Governance and Gender: Compliance and beyond in addressing gender discrimination in global value chains}

The expansion of global value chains since the 1980s has been driven by retailers and brands seeking lower cost production through sourcing from low wage developing countries. In many sectors (such as garments and agri-food), women have been drawn into employment as a source of cheap labour in countries where labour force participation was previously limited. Many women face a decent work deficit with few rights, limited protection, lack of voice or access to organisation through independent unions (Elson and Pearson 1981; Pearson 1998; ILO 2016; Barrientos 2019). Women face particular challenges arising from combining paid work with unpaid care responsibilities and entrenched discrimination. This often includes sexual harassment and gender-based violence both within and beyond workplaces (Fair Wear 2018; ITUC 2018).

Some argue that global sourcing contributes to a 'regulatory void' in which developing country governments either chose or were pressured to reduce labour standards (for example in export processing zones) to remain competitive in global markets (Sengenberger 2002; Applebaum 2013). In global value chains labour conditions are affected by the practices of buyers operating beyond the judicial boundaries of their suppliers. Buyers constantly pressure suppliers to reduce costs and increase efficiency through just-in-time (JIT) production, whilst requiring suppliers to meet stringent quality standards (Barrientos 2013; ILO 2017; Oxfam 2018). Many suppliers deal with these pressures by increasing their use of casual, temporary or contract labour. Women are often viewed as more 'subordinate', and concentrated in precarious forms of work.

On the other hand, global sourcing facilitated a process of transnationalism in labour-standards settings. Civil society organisations, including global unions and NGO, have addressed this void through diverse strategies of worker organisation, advocacy and media campaigns (Waterman and Wills 2001). In response, many MNC introduced codes of labour practice to address poor labour conditions within their supply chains. This led to the rise of private labour governance systems, the better of which are based on Core ILO Conventions (Hendrickx et al. 2016). The expansion of global sourcing has therefore contributed to different forms of governance of labour standards emerging in 
cross border supply chains, involving public, private and social actors. One example is Global Framework Agreements signed between global trade union federations (such as the IUF) and multi-national companies (such as Danone, Sodexo and Melia) on sexual harassment (ITUC 2018).

\section{GVC Analysis - Governance and Gender}

Global value chain analysis has placed much emphasis on the role of governance - the setting of the norms, rules and policies that frame participant actions. For long the focus was mainly on private governance, and strategies of lead firms coordinating their value chains across international borders (Gereffi, Humphrey, and Sturgeon 2005a). Social governance has largely been conflated with private governance under the umbrella of social compliance implemented by MNC, and the role of public governance overlooked. However, it is increasingly recognized that value chain governance involves a diverse range of civil society and state actors (Ponte and Sturgeon 2014; Alford 2016). Three dimensions of governance - private, public and social - are now identified as playing crucial roles (Mayer and Posthuma 2012). The differentiation of social governance, we will argue, is particularly important from a gender perspective.

In a GVC context, private governance is defined as the power of lead firm strategies to coordinate and distribute resources along their value chains. This mainly relates to product, environmental and labour standards applied by lead firms and private sector bodies (Gereffi, Humphrey, and Sturgeon 2005b; Gibbon and Ponte 2005; Nadvi 2008, 20008). ${ }^{1}$ Public governance involves rules, regulations and government policies within nation states, as well as international agreements and multilateral institutions, that can affect the operation of GVC (Gereffi 2005; Neilson and Pritchard 2009; Smith 2015; Horner 2017; Phillips, Mayer, and Posthuma 2017). Social governance relates to the ability of civil society organizations, including trade unions, NGO, social movements and multi-stakeholder initiatives (MSI), to influence social norms, policies, business practices, institutions and markets at national or international levels. This includes advocacy and campaigns that highlight labour rights abuses in global value chains, and targeting the purchasing practices of MNC (Mayer and Posthuma 2012).

Differing concepts have been applied to analyse the role of multiple actors in governance within the GVC literature. These include 'modular' (Ponte and Sturgeon 2014); 'trans-scalar' (Alford 2016); and 'hybrid' (Bair 2017) governance. Here we draw on Bartley's (2011) concept of 'inter-layered' governance highlighting the combined roles of private and public actors in labour standards. We extend this to also highlight social governance in order to gender the analysis. The three dimensions - private, public and social - form three pillars of 'polycentric' governance that can influence outcomes in relation to decent work. Below we argue they are inter-layered as no dimension alone is

\footnotetext{
${ }^{1}$ Private governance is defined here as incorporating both internal and external dimensions of corporate policy (including value chains), whereas corporate governance relates more narrowly to a company's relation to its own employees and shareholders (Palpacuer 2008).
} 
sufficient to address gender rights of workers, yet combined they can influence the gendered rules and norms governing labour standards in global value chains.

Feminist political economy also informs a gender analysis of governance, and why the role of social governance needs to be highlighted in GVC. Feminist analysis transcends the gender division of labour between the productive sphere for markets involving paid work and reproductive sphere caring for current and future generations, largely involving unpaid work by women within households (Himmelweit 2000; Hoskyns and Rai 2007). Societal norms that subordinate the role of women within this gender division of labour also shape the undervaluation of women's paid work when they enter global value chains. Entrenched discrimination is reflected in women's concentration in lower paid and more precarious work, prevalence in home based informal work, and vulnerability to gendered issues including sexual harassment (Fairwear 2018). Private governance focusing primarily on the commercial sphere of linkages between firms across borders and paid work largely overlooks the societal underpinnings of gender discrimination.

In relation to public governance, feminist political economy, highlights a gendered division between the public and household domains, where men dominate in the public domain of state and government (Goetz 1997). The embeddedness of institutions in social norms configures the gender profile of public governance. Feminist political economy has contributed to critical analysis of gender bias within national and international institutions (Pearson and Seyfang 2001; Hoskyns and Rai 2007; Stewart 2011). Extending this argument, some posit that markets are themselves gendered institutions that act as bearers of gendered rules and norms (Elson 1999; Beneria 2007). However, focusing on public governance risks overlooking the societal norms and gender division of labour underpinning the setting of rules and policies that can affect value chains.

From a gender perspective, the role of social governance is distinct from private governance that focuses on the commercial sphere alone. Social governance can transcend the spheres of commercial production and social reproduction. It provides a channel for representation and voice for precarious workers whose rights are shaped across both spheres. It identifies the influence some trade unions and NGO that incorporate a gender focus ${ }^{2}$ can have in highlighting labour rights abuses facing more precarious workers who are often women, and challenging the commercial purchasing practices that compound precarious work. Social governance can in some circumstances challenge gendered power asymmetries entrenched within global value chains. The inter-layering of social with private and public governance, explored further below, thus has the potential to promote more integrated approach to addressing gender inequalities that arise in the societal sphere and persist within GVC.

\footnotetext{
2 Trade unions and NGO are not homogenous organisations. Some are male dominated, and fail to sufficiently address gender issues. Others (e.g. SEWA in India and Women Working Worldwide in the UK) are specifically gender focused. The argument here is the need to recognise the potential role gender focused organisations can play in addressing gender discrimination within GVCs (Barrientos 2019).
} 


\section{Limits of private governance - social compliance}

Private governance of labour standards arose largely in response to social governance involving advocacy and campaigns by NGO and trade unions against MNC, highlighting poor workers' rights and labour abuses in their global value chains. Poor labour conditions reflect the inability or unwillingness of governments to regulate the private sector on the premises that it would reduce foreign investment and trade. As such, the failure of governments to exempt companies from adhering to labour standards through the creation of export processing zones, and neglect their own responsibilities to enforce legislation and protect workers' rights, helped fuel a race to the bottom in labour standards. Retailers and brands implemented codes of labour practice and CSR strategies as part of wider private governance of standards across GVC (Marx and Wouters 2016). These include product standards (e.g. technical and safety specifications) and process standards (e.g. environmental conditions and labour standards) (Nadvi 2008; Henson and Humphrey 2010). Codes of practice allow large retailers and brands to ensure the quality of products, and to avert reputational risk to themselves from campaigns over poor labour conditions. The better codes of labour practice require implementation of national labour regulation, and incorporate Core ILO Conventions and related UN human rights conventions (Jenkins, Pearson, and Seyfang 2002; Barrientos and Smith 2007).

'Social compliance' encapsulates the part of private governance that evolved through the implementation of codes of labour practice and a monitoring logic using social audits. Auditing practice led to the expansion of an army of private social auditors deployed to monitor supplier compliance with buyer codes across most consumer goods industries. Social compliance is self-regulatory in nature, and drawn up under CSR remit. In complex value chains, MNC assume the role of accountability holders, externally imposing accountability and auditing practices on developing country suppliers (Sinkovics, Hoque, and Sinkovics 2016). Social compliance is now an enormous industry, estimated to be valued somewhere between US $\$ 15$ and $\$ 80$ billion annually, involving many large international auditing firms and independent not-for-profit organizations (Terwindt and Armstrong 2018).

Despite the large resources, social compliance has had only limited impact on improving labour standards in global value chains. A number of studies have shown that, whilst social audits are more able to assess measurable standards that are easily documented (e.g. wages, overtime, health and safety), they have proved ineffective at assessing enabling rights, including freedom of association and discrimination (Barrientos and Smith 2007). In particular, audits often fail to identify gender discrimination or harassment as non-compliance issues (BSR $2018 b)$. For example, a study of social audits undertaken in 2,447 factories in Asia between 2009-2012 found less than 1\% non-compliances with no discrimination (Distelhorst and Locke forthcoming). Yet many of the audits were undertaken in countries where gender discrimination is deeply embedded. 
These included Bangladesh and India that rank 119 and 125 respectively in the UN Gender Inequality Index. ${ }^{3}$. Also Indonesia, where an independent impact assessment commissioned by the ILO/IFC Better Work programme, using a different methodology, found that $88 \%$ of workers complained sexual harassment was an issue in their factory - almost the reverse findings to social audits (Better Work 2016; Barrientos 2019).

Social audits provide an attestation service (Kinney 1988) which technically monitor compliance to standards and codes of labour practice. They are based on technocratic practices that often lack of social contextualisation, and take little account of supplier business culture or policies (Locke 2013). They often involve third party auditors that do not have specific human rights expertise and lack investigation and prosecution powers (LeBaron and Lister 2015; ETI 2015). One analysis of the garment industry in Bangladesh concluded that the main changes resulting from the social audit process operate on the financial selfinterest of the supplier (i.e. maintaining contracts with MNC) and are "fundamentally temporary and reversible in nature" (Islam et al. 2018: p. 212). The Rana Plaza factory collapse in Bangladesh in 2013 killed over 1,100 mainly female garment workers and occurred only weeks after the factory had passed a social audit (Terwindt and Armstrong 2018). Social compliance lacks accountability on labour practice, and suppliers often move in and out of compliance (Locke 2013).

Over recent years, recognising the limits of code of conduct and social audits in governing global suppliers, a number of leading retailers and brands have started to look 'beyond compliance' at wider initiatives to promote social as well as environmental standards within their global value chains. It reflects recognition that despite the expenditure of huge resources, poor labour conditions continue to persist in GVC.

GVCs criss-cross national borders, where regulatory and political frameworks greatly differ from one country to another. There is a disconnect between the real power and influence of MNC over the implementation of labour standards, companies' accountability towards stakeholders, and their legal requirements (Ruggie 2018). As it is, social compliance is generally an add-on - an incremental cost - to normalised business practices and global chains governance. It does not effectively challenge MNC purchasing practices underpinning many labour rights abuses among suppliers (Barrientos 2019). On the other hand, in global value chains legal compliance is insufficient to impose labour standards, as MNC barely exist under international law, and domestic law is usually unable to go beyond national borders to reach companies in their position of international entities coordinating GVC.

\section{Role of Public Governance - United Nations Guiding Principles}

\footnotetext{
3 http://hdr.undp.org/en/composite/GII [accessed March 2018]
} 
In light of global governance challenges in which MNCs have increasing influence on people's lives, a new Business and Human Rights (BHR) framework is emerging. This transcends the dichotomy between mandatory and voluntary approaches, generating a new regulatory dynamic with the potential to mediate public, private and social governance (Ruggie 2013). BHR is "in part a response to CSR and its perceived failure" (Ramasastry_2015 _. encouraged in recent years by the rise of global standards of corporate accountability for human rights developed by International Governmental Organisations ${ }^{4}$ (Islam and McPhail 2011; Muchlinski 2003). The focus shifts from social and legal compliance to corporate accountability, where all the actors in the global governance setting - public, social and private - can benchmark business conduct against internationally recognised human rights standards. MNCs are beginning to adopt the UNGP as part of their move beyond compliance, towards a more integrated approach to workers' rights.

The UNGP provide a common international conceptual and policy framework aimed at adapting the human rights regime to business. The Principles are built on differentiated but complementary duties and responsibilities. They comprise three core pillars: the State duty to protect against human rights abuses by third parties, including business; the corporate responsibility to respect human rights; and the need for more effective access to remedies (Ruggie 2008). The direct corporate responsibility to respect exists independently of States' duties, and it does not entail a merely passive attitude of not doing harm but rather positive steps that go beyond compliance. The Principles attribute a role to social actors that is supplemental, recognising their monitoring function on business impacts, assessment and accountability practices. Affected stakeholders and their representatives - such as NGO and trade unions - can also leverage for the adoption of context-sensitive practices, and ensure the availability of effective grievance mechanisms.

The implementation of the UNGP represent a site for convergence among heterogeneous governance regimes in value chains that cross-global, national and local scales. This is important in a GVC setting, where adverse impacts on human rights can occur as a consequence of economic activity of MNC located beyond the legal jurisdiction of individual suppliers - instead of being confined within national borders (Backer 2015). The UNGP go beyond national regulatory compliance and try to overcome the difficulties of operating across different legal regimes, compensating fragmented state-based authority structures through corporate accountability and human rights due diligence (Ruggie 2014).

\footnotetext{
4 Among these: the UNGP endorsed by the Human Rights Council in 2011 https://www.ohchr.org/documents/publications/GuidingprinciplesBusinesshr eN.pdf (last accessed May 2019); the OECD Due Diligence Guidance for Responsible Business Conduct launched in 2018 http://mneguidelines.oecd.org/OECD-Due-Diligence-Guidance-for-Responsible-Business-Conduct.pdf (last accessed May 2019); the ILO Tripartite Declaration of Principles Concerning Multinational Enterprises and Social Policy 2017 https://www.ilo.org/wcmsp5/groups/public/---ed emp/---emp ent/--multi/documents/publication/wcms 094386.pdf (last accessed May 2019); the 2030 Agenda for Sustainable Development, adopted by the UN in 2015 sustainabledevelopment.un.org (last accessed May 2019).
} 
The UNGP provide a common language to various actors and a shared accountability tool - i.e. human rights due diligence - allowing for a level of fluidity among different governance regimes. In line with Ruggie's aspirations, the UNGP are characterized by a dynamic dimension that should "trigger an iterative process of interaction among the three global governance systems, producing cumulative change overtime" (Ruggie 2017:17).

Even if the UNGP attribute a supplemental - rather than a primary - role to social actors, CSO proactively guide and promote the implementation of the Principles. Actors in the sphere of social governance are de facto functioning as intermediaries between public and private actors, facilitating the adoption of the UNGP and other BHR standards, enhancing exchange between different governance regimes. As intermediary players, social actors possess governance capabilities, such as technical expertise and direct access to target actors, that lack in public actors (Abbott et al. 2012). Multi-stakeholder initiatives and CSO can play a pivotal role in expanding the reach and effectiveness of the UNGP framework, leveraging all the players involved to act in favour of rights holders, and assisting them in the achievement of corporate accountability towards human rights.

Social governance can further enhance the adoption of a gender perspective in the implementation of the UNGP. CSO provide workers with collective channels to voice human rights concerns both within workplaces (via trade unions) and wider communities (via NGO). Not all unions and NGO take a gender focus, however where they do, some provide a channel for vulnerable groups, such as temporary, casual and informal workers who are often women, which may be overlooked in more formal institutional and workplace settings (Barrientos 2013). They can help to raise gender issues (such as discrimination and sexual harassment) underpinned by social norms that subordinate women, and transcend boundaries between commercial workplaces and wider sphere of social reproduction.

Until recently, the debate around the UNGP lacked a specific gender focus. In 2017, the UN Working Group on Business and Human Rights (UNGW) recognised that inadequate attention has been given to gender in the implementation of the UNGP. ${ }^{5}$ It highlighted the need to differentiate impacts of business-related human rights abuses on women and the additional barriers that they face in accessing effective remedies to redress such abuses. In the implementation of the UNGP companies have a direct responsibility to respect women's rights in different settings across their global value chains. They need to factor in genderbased considerations in the assessment of their impacts on women, including an evaluation on how societal roles and expectations increase adverse effects, and

\footnotetext{
5 Following the $6^{\text {th }}$ UN Forum on Business and Human Rights in November 2017, the UNGW launched a thematic project to unpack the gender dimension of the UNGP, aimed at raising stakeholders' gender-sensitivity and developing guidance for States and business on the matter. ${ }^{5}$ The project should conclude in June 2019 with the release of guidance for States and companies on the matter. https://www.ohchr.org/EN/Issues/Business/Pages/GenderLens.aspx. Accessed November 2018
} 
how these could be addressed, as there is a risk of reinforcing or exacerbating existing gender discrimination by adopting gender-neutral policies. ${ }^{6}$

\section{Interlayering public, private and social governance - company initiatives on gender}

Multi-stakeholder initiatives (MSI) provide an example of partial interlayering of private and social governance, although public governance has to date played a lesser role. Many MSI are long established, bringing together companies, NGO, and sometimes trade unions, in alliances to promote workers rights. The move 'beyond compliance' has enhanced company participation in MSI. MSI can complement broader human rights principles through the UNGP, and help drive the BHR agenda. Some MSI inform a gender sensitive approach to workers' rights that links private and social with public governance based on corporate accountability rather than voluntarism. This section examines the potential opportunities and limitations of company driven gender initiatives, often undertaken in collaboration with civil society organisations. It considers the advantages of an interlayered governance approach, drawing on an example from a Kenya tea company informed by experience in the flower industry. This illustrates the potential role UNGP could play in scaling up a gendered approach to business and human rights.

The UK Ethical Trading Initiative (ETI) provides an example of MSI influence on addressing gender equality as part of broader business responsibility towards human rights. The ETI, established in 1998, is an alliance of 90 UK companies with a combined turnover of over $€ 166$ billion in 2017, as well as 17 NGO and four union federations. All ETI members commit to the Base Code, ${ }^{7}$ which is based on the ILO conventions and requires compliance with national labour regulation in sourcing countries. Over the years, in line with regulatory developments both at national and international level, ETI institutional logic was well-placed to put the emphasis on towards BHR and shift companies away from a traditional CSR approach. The ETI brings together private and social governance for the affirmation of international labour standards in GVC, acting as a translator of the public actor goal, that is, the assignment of a direct responsibility to business towards human rights. The ETI provides learning and promotes respect for workers' rights in members' global value chains. ${ }^{8}$ It now acts as an intermediary actor between public institutions that have endorsed the UNGP and target (private) actors. The ETI therefore facilitates an interlayered governance arrangement, also helping the public actor - states and intergovernmental institutions - to educate and mobilize the target actors towards corporate accountability.

\footnotetext{
${ }^{6}$ See the Report of the Working Group on the issue of human rights and transnational corporations and other business enterprises to the General Assembly - A/72/162, Para 28.

7 See http://www.ethicaltrade.org [accessed June 2018]

${ }^{8}$ See for example the ETI Base Code Guidance: Gender Equality (B), Gender and human rights due diligence, available at https://www.ethicaltrade.org/sites/default/files/shared resources/Base $\% 20$ code $\% 20$ guidance $\% 2 \mathrm{C} \% 20$ gender $\% 20 \mathrm{e}$ quality\%2C\%20Part\%20B.pdf [accessed November 2018].
} 
The UK ETI developed a Human Rights Due Diligence Framework in consultation with its tripartite members (companies, trade unions and NGO) that goes beyond social compliance and interprets the requirements and application of the UNGP in relation to labour rights in global supply chains. ${ }^{9}$ A gender-specific guide was also developed for a more explicit and deliberative approach to tackling gender related labour rights (ETI 2018). This involves a four-step approach aligned to the UNGP HR due diligence approach: a) identifying gender and labour rights risks; b) identifying corporate responsibility and leverage to tackle this; c) mitigating, remediating and managing labour rights violations affecting women workers; and d) monitoring, reviewing and reporting on actions taken.

\section{ETI Gender Assessment}

As part of the process of developing its gender and human rights strategies, the ETI initiated a gender assessment of ten company members that had adopted gender initiatives as part of the governance of their global value chains. The assessment was undertaken in $2017 .{ }^{10}$ The study was not a representative sample of ETI companies or initiatives, nor was the aim to undertake a full assessment of each initiative. The main goals of the study were to: (a) understand the motivation and process through which companies are addressing gender issues within their value chains; (b) gather better data and information on the types of engagement by companies in gender initiatives given reporting is very variable; (c) enable companies to learn from one another and inform learning for other ETI members and development of the ETI gender strategy and Base Code Guidance; (d) advance the academic knowledge on the implementation of gendered due diligence practices in GVC.

The analysis drew on an 'action research', participatory method through which researchers are directly involved in the co-production and implementation of learning to promote transformative change (Eden and Huxham 1996; Burns 2007). The researchers adopted a qualitative and inductive approach to the inquiry, combining multiple data sources. Data gathering included interviews, informal conversations, and documentation analysis. The 10 companies volunteered by responding to a call to all member companies asking for participants in the study. Participating companies were assured anonymity. The assessments were undertaken by a combination of ETI gender consultants and academic researchers. Each company assessment was based on a review of relevant documentation for that company's engagement in gender initiatives (which on average were three or more), UK based interviews with relevant company personnel and Skype interviews with key suppliers and initiatives where based in other countries.

\footnotetext{
${ }^{9}$ See https://www.ethicaltrade.org/resources/base-code-guidance-gender-equality.

10 This gender assessment was funded by an ESRC Impact Acceleration Award to the University of X, and a DFID award to the ETI. The findings presented here represent the views of the authors alone, and not the funding bodies or ETI.
} 
The focus of the research was limited to exploration of the companies' governance approach and strategies to addressing women workers' rights, which is the main focus of this paper. ${ }^{11}$ An advisory group that involved ETI company, NGO and trade union representatives provided guidance. The process also involved three workshops, involving all researchers, companies and ETI staff, and feedback sessions between individual researchers and companies. An info-graphic was subsequently made publicly available providing an overview of the findings.

\section{Assessment findings}

Table one provides a brief overview of findings from 9 of the assessments as one company only provided partial information and has been excluded from detailed empirical analysis. The companies were separately engaged in 32 initiatives across 12 countries (with some overlaps between countries) covering 115 workplaces involving approximately 170,000 workers and smallholders. The data on workers reached needs to be treated with caution, as there was a lack of systematic data gathering, nor was the data collected necessarily disaggregated by sex. Not all initiatives were specifically gender focused, but all incorporated women as an important target group. Some initiatives were focused on one issue, but many had a variety of aims.

The assessment indicated that benefits provided for women workers include increased mentoring to advance women's access to skills training, health services, maternity benefits, education, life skills, leadership and financial management. The main focus of the highest number of initiatives was on reproductive health (7), for example improving factory systems for workers health services and empowering women workers as health champions. Many initiatives focused on training for skills development (5) or supported workers' capabilities, voice and leadership (5). Three initiatives focused primarily on gender-based violence, for example awareness raising, capacity and policy development to address this in garment factories in Asia. Three initiatives were focused on enhancing value capture by women working in smallholder production. Some initiatives aimed to improve pay and conditions for women workers, including progress towards a payment of living wages. Others also addressed issues around gender-based violence, and included awareness and capacity building training, and new policies and procedures for reporting and remediation where incidents are identified. Some companies aimed to reach out to all workers within selected production sites; others were more intensive and reached smaller numbers of workers within sites.

The overall assessment was that in the past ten years, there have been advances in the awareness and approach of some retailers, brands and suppliers towards women workers in global value chains. Gender is now on the agenda of many companies, and is beginning to form part of their 'beyond compliance'

\footnotetext{
11 The methodology did not include direct participation by workers, in part due to the focus on governance by companies in collaboration with other stakeholders, and also time and resource limitations. The authors have examined workers' perspectives in related research published elsewhere [Author References to be inserted]
} 
governance strategies. There is evidence that some companies and their suppliers are keen to engage with a wide range of stakeholders to address gender inequality in their global value chains, and recognise the role interlayered governance can play. At the same time, a number of limitations were also identified by the assessments - they were diverse in their aims, tended to be fragmented, and only benefit specific groups of workers. As such, their ability to be scaled up is limited.

Table 1. Summary of Company Gender Initiatives Examined

\begin{tabular}{|l|l|l|l|l|l|l|l|}
\hline & & & & & \\
\end{tabular}

Notes:

n/a - information not made available;

One company is excluded from reporting in the table as insufficient data was provided.

* Data on workers reached needs to be treated with caution as data gathering not systematic.

** Some companies have also adopted other UN-based initiatives, including the UN Women's Empowerment Principles and Social Development Goals, not analysed here.

\section{Governance opportunities and limitations}

All the initiatives studied here were channelled through private governance, mainly the CSR departments of companies. However, the assessment found evidence all engaged in a collaborative approach, mainly with civil society organisations, including not-for-profit initiatives, as shown in Table 1. Most involved company participation in independent external civil society led programmes, whilst some (10) were company-led and undertaken in collaboration with civil society organisations. The types of external organisations involved included international and local NGO, non-profit business consultancies or auditing companies and multi-lateral organisations. There were some 
overlaps between the initiatives, with more than one company engaged in the same civil-society led initiative, and a total of 27 initiatives involved. Given supplier anonymity, it was not possible to assess whether different companies were engaged in initiatives on the same production sites.

Some initiatives involved links to government programmes, supporting women workers to access government services. However, as shown in Table one, government collaboration was far less prevalent than with civil society organisations. Only one company had a stated policy of government engagement to promote gender equality, which will be examined in more detail below.

The analysis highlighted the limitations of private governance as a channel for addressing gender discrimination in GVC. At present there is fragmentation across initiatives, and they lack a coherent overall strategy. Companies themselves acknowledged that the 'pieces of the quilt' were often not joined up and they lacked a strategic approach. Most of the initiatives were not designed based on a needs assessment or as a part of the companies' human rights due diligence process. There was little or no consultation with workers on the design of the interventions in advance. A critical missing element was a lack of engagement with trade unions and other effective dialogue mechanisms, or the use of formal grievance and remedy processes. None of the initiatives was aimed at challenging the business model of cost reduction and just in time production that helps to drive precarious work undertaken by women. There was no systematic assessment of the impacts generated for women, nor their prevention, mitigation or remediation.

Interviews with company personnel indicated a number of the initiatives were driven by philanthropic more than human rights motives. The initiatives were part of a 'top down' approach by companies as part of their CSR programmes linked to private governance. There was little evidence that the businesses had a policy or strategy to address gender inequality entrenched in their global value chains. As such, there was limited coherence or ambition to replicate these projects or approaches in other parts of the business, extend them to other suppliers, nor to scale them up beyond the scope of the selected factories or farms involved.

In sum, analysis of the initiatives promoted by the companies revealed an approach to gender-related issues that was generally neither systematic nor strategic within the businesses. The initiatives were often reactive to a specific challenge or to another institution led-action, even if they usually represented recognition of a business responsibility towards women's rights. These were independent from States' duties to protect women's and labour rights. The initiatives were generally not part of a systematic implementation of the human rights due diligence process set out in the UNGP.

\section{Kenya tea - illustration of interlayered governance}

One initiative, however, stood out as making important progress. A tea company, drawing on experience in the Kenyan flower sector, developed a strategy in its 
Kenyan business that recognised gender discrimination and sexual abuse as human rights issues that were impacted by the commercial operations of the business. It provides a practical example of the interlayered roles social, private and importantly public governance can play at different stages as addressing gender issues and rights gains prominence in a company.

Social governance played an initiating role driving change from the early 2000s in the form of advocacy and campaigns over workers' rights abuses in Kenyan tea and flowers. Abuses identified included systematic gender discrimination, sexual harassment of women workers by male supervisors, women concentrated in insecure work on temporary contracts and lack of procedures for worker complaints or remediation (Dolan, Opondo, and Smith 2004; Said-Allsopp and Tallontire 2015). Public governance later had a catalytic effect when changes to the Constitution in Kenya in 2010 raised gender equality as a key issue that business needed to address. ${ }^{12}$ Following changes by some flower companies, the tea company responded to civil society pressure, and changes in the constitution to embed policy changes in their core business operations.

The tea company ( $G$ in Table 1) developed a gender strategy as part of its overall sustainability programme that was later linked to promoting the UN Business and Human Rights framework as well as the UN Sustainable Development Agenda. Changes included: appointment of a Gender Empowerment Manager; developing new policies and procedures to address gender bias in recruitment; and establishing gender committees, providing women workers with channels for raising complaints and remediation.

In accordance with the Kenya Bill of Rights (2010), the company also set a medium-term target of a minimum 33\% representation of women at every level within the company (including different categories within the workforce and management). The company's longer-term target is to achieve $50 \%$ female representation at all levels of the workforce, including senior management. It therefore integrated a strategy to promote gender equality across its business operations, rather than a more philanthropic approach supporting specific groups of women workers.

The programme was rolled out from 2014. The company also introduced monitoring and evaluation procedures to track the effect of its policies. Early signs were positive in terms of progress. Overall between 2014-7, women's representation rose from $39 \%$ to $42 \%$ of workers and management across the company. It also developed a talent pool of women able to move to more senior positions in future. In the company's assessment, it succeeded in moving beyond a narrow focus on compliance, to the implementation of a more strategic approach to gender equality. The company also recognised that gender equality made good business sense - they were able to show raised productivity and efficiency, commercial success, and the ability to produce better quality

\footnotetext{
12 Constitution of Kenya 2010, in particular Chapter Four "The Bill of Rights", and articles 59 and 60. http://www.kenyalaw.org/lex/actview.xql?actid=Const2010 [accessed November 2018].
} 
products. ${ }^{13}$

The ETI study did not include interviews with tea workers as part of the assessment (see Footnote 11). However, the tea supplier treads a similar path to that already followed by some Kenyan flower companies that were subject to even more vigorous media campaigns than tea in the early 2000s. These involved trade unions, NGO -both in Kenya and Europe-, as well as the Kenya Human Rights Commission (KHRC). Approximately 100,000 workers are employed in Kenyan flowers, 75\% female (Barrientos 2014). Campaigns highlighted poor labour conditions including constantly renewed temporary contracts, violation of health and safety rules in greenhouses, and sexual harassment by male supervisors. Supermarkets providing orders at short notice led to sudden overtime demands, causing particular problems for childcare. A complaint was also made to the ETI by a UK NGO member. The ETI organized a delegation (including UK supermarket representatives) to visit Kenya in November 2002.

Larger flower companies subsequently made a number of improvements in the way they approached human resource management, and the terms and conditions of employment. Health and safety improved, and a significant number of women workers were switched from temporary to permanent contracts. Some flower farms set up gender committees tasked with addressing issues such as sexual harassment and discrimination, providing a channel for worker complaints and remediation. Workers in subsequent research studies reported improvements in employment conditions and less on-farm sexual harassment (Oxfam/IPL 2013; Evers, Amoding, and Krishnan 2014; Said-Allsopp and Tallontire 2015) ${ }^{14}$ More women subsequently became supervisors and moved into managerial positions (Barrientos 2019). Improvements in Kenya's employment law in 2007 and Constitution in 2010 further helped to enhance labour standards (KHRC 2012). The business benefits of the changes also became clear over time. Enhancing the rights of a largely female workforce led to lower labour turnover, more committed skilled workers, higher productivity and quality (IFC 2013). Although, not all farms made progress, and workers continue to complain that nominal wage rises have failed to provide a living wage (Oxfam/IPL 2013).

In sum, examples from the tea and flower sectors provide learning in relation to gender and the potential roles interlayered social, private and public governance can play. Companies did not set out to involve different actors, yet over time civil society and government influenced the development a more integrated approach linked to their business operations. Social governance initially raised gender awareness in Kenya flowers and tea, leading to a collaboration with civil society

\footnotetext{
13 The information provided here is based on a review of company documentation, an independent review and social compliance reports, interviews with company personnel (managers, HR and Gender Empowerment Manager) and civil society organisations undertaken in 2017. Further research would be required to assess workers' experience of the changes.

14 Sexual harassment, which is a deeply embedded social issue, is reported to have reduced on site but continues at community level.
} 
organisations in developing a gender strategy. Private governance provided the implementation channel, extending a gender strategy within the company to its business operations and human rights commitments. Public governance played a catalysing role by changing the legislative environment within Kenya on gender discrimination and representation of women. These actions by different players are in line with the international framework for business and human rights set by the UNGP. Combined, the interlayering of different governance dimensions helped to develop and anchor a gender strategy into the business operations of the company.

\section{Gender and interlayered governance of workers' rights}

Combining the three governance layers links different channels for addressing gender rights abuses that are societally embedded. Public governance plays an increasing role in setting the standards and demanding transparency and human rights due diligence linked to global value chains. Private governance provides a channel for addressing gender rights within global production, with a recognised direct responsibility towards gender rights. And social governance has a central role in the adoption and mediation of a gender-responsive UNGP, as CSO and MSI pressure business and demand corporate accountability. As analysed in Section 3 , some companies are starting to take responsibility for women's rights, even if a proper corporate accountability system towards gender equality is still in its infancy.

To date, despite some MNC leading the way, the majority of companies in GVC struggle to implement systematic human rights due diligence process and take full responsibility for their impacts on women (CHRB 2018). Likewise, up to now, States have not paid adequate attention to gender equality in their duties under the UNGP (Human Rights Council 2019). As a result, social actors are able to provide a catalyst in pushing other players to adopt a gender-responsive due diligence system. CSO and MSI can benchmark private actors against internationally recognised human rights frameworks (Commentary - Principle 12, Human Rights Council 2011) and influence the adoption of gender-sensitive norms. They can leverage business to be context-sensitive, recognising embedded and highly complex gender-norms, and making sure that companies do not perpetuate or benefit from intrinsic gender inequalities that go beyond the workplace (Bourke-Martignoni and Umlas 2018). Social governance often challenges the business models of JIT and cost reduction that underpin precarious work and reinforce gender discrimination within GVC.

Women rights holders experience business impacts in different ways and cannot be considered as a homogeneous group. Companies do not have the knowledge to meaningfully address the complex and structural forms of inequality in different segments of their GVC, or discriminatory social norms, patriarchal power systems and gender stereotypes (Human Rights Council 2019). CSO provide context-sensitive guidance and give women workers a voice, acting as intermediaries for a gender-sensitive implementation of the UNGP. 
To promote a gendered rights approach, companies should seek to understand the concerns of affected rights-holders by mean of direct consultation, taking in consideration language, cultural and other possible barriers to a dialogic engagement. Where a direct consultation with rights holders is not possible, companies should refer to civil society organisations (Commentary - Principle 18, Human Rights Council 2011), ensuring meaningful participation of the parties involved. This latter is a key characteristic of a business and human rights approach to gender inequality, which differs from a CSR approach where often stakeholder engagement is symbolic and only seeks external legitimisation (Archel, Husillos, and Spence 2011).

Worker representation and engagement remains critical to achieving decent work in GVC. Through independent trade unions workers can exercise their right to freedom of association and negotiate the terms and conditions of work directly with their employers. However, the UN Working Group report recognises this is not always available to women workers (A/HRC/41/43). Where official trade unions and other forms of independent representation are not feasible or available - particularly to vulnerable women workers on temporary or agency-based contracts- the role of intermediaries such as multistakeholder initiatives can help bridge this gap in the short to medium term.

The cases illustrated in Section 3 demonstrate how social governance has a primary and substantive role to play in advancing a BHR approach. Currently, public and private actors alone are not able to change the rules of the game, allowing to switch the business attitude from voluntarism to accountability. A more systematic and integrated approach towards gender inequality is possible through the intermediary role of social actors, their knowledge, leverage and influence over private actors for the implementation of the UNGP.

\section{Conclusion}

The coordination of global value chains by MNCs has been proven highly challenging for the protection of women workers' rights. Private governance based on social compliance has largely failed to identify or address gender discrimination in global value chains. There is greater recognition of the importance of collaboration between company, civil society and government actors for the advancement of workers' rights. This fosters a link between public and private governance regimes linking the state duty to protect and business responsibility to respect human rights. A core argument here is that social governance also has an important role to play in GVCs.

The adoption of the UNGP cogently links private and public responsibilities towards the protection and respect of women workers' rights. However, UNGP has only recently addressed gender. This paper argues the new regulatory dynamic which emerges from the UNGP and liaises public and private governance also needs to integrate social governance as a way of meaningful engagement and participation of rights-holders, particularly vulnerable groups including women. Civil society can help to mediate links between public and private actors; some NGOs and trade unions (by no means all) address 
underlying gender discrimination and rights abuses that transcend paid work in commercial production and wider societal norms that subordinate women. Some go further in challenging the purchasing practices of MNCs that compound the types of precarious work in which gendered rights abuses are prevalent.

In sum, an inter-layered governance regime and a systematic approach towards corporate accountability represent the way forward to overcome a CSR-based approach. The public actor sets principles and parameters of reference towards BHR. And social governance, through trade unions and NGO, could influence the implementation of new BHR standards, guiding private actors to capture the complexity of business-related impacts on women in global production. Both public and social actors can hold private actors accountable for their direct responsibility towards women's rights, demanding the identification, prevention, mitigation and accounting on potential or actual abuses against internationally recognized rights. Combined, an interlayered approach involving public governance by states and intergovernmental institutions, private governance by companies, and social governance by civil society organisations and multistakeholder initiatives have the potential to provide a more effective route to gender equality in global value chains. However, promoting gender equality through the human rights agenda and the implementation of the UNGP still has a long road to travel.

\section{REFERENCES}

Abbott, Kenneth, Philipp Genschel, Duncan Snidal, and Bernhard Zangl. 2012. 'Orchestration: Global Governance Through Intermediaries'. Social Science Research Network. http://ssrn.com/abstract=2125452.

Alford, M. 2016. 'Trans-Scalar Embeddedness and Governance Deficits in Global Production Networks: Crisis in South African Fruit'. Geoforum 75: 52-63.

Applebaum, R. 2013. 'Global Wage Trends for Apparel Workers 2001-2011'. Washington D.C.: Workers Rights Consortium.

Archel, Pablo, Javier Husillos, and Crawford Spence. 2011. 'The Institutionalisation of Unaccountability: Loading the Dice of Corporate Social Responsibility Discourse'. Accounting, Organizations and Society 36 (6): 327-43. https://doi.org/10.1016/j.aos.2011.06.003.

Backer, Larry Catà. 2015. 'Governance Polycentrism or Regulated Self-RegulationRule Systems for Human Rights Impacts of Economic Activity Where National, Private and International Regimes Collide'. https://papers.ssrn.com/sol3/papers.cfm?abstract_id=2557829.

Bair, Jennifer. 2017. 'Contextualising Compliance: Hybrid Governance in Global Value Chains'. New Political Economy 22 (2): 169-185.

Barrientos, S. 2013. 'Corporate Purchasing Practices in Global Production Networks: A Socially Contested Terrain'. Geoforum 44: 44-51. 2019. Capturing the Gains: Gender and Work in Global Value Chains. Cambridge: Cambrdige University Press.

Barrientos, S, and S Smith. 2007. 'Do Workers Benefit from Ethical Trade? Assessing Codes of Labour Practice in Global Production Systems'. Third World Quarterly 28 (4): 713-29. 
Barrientos, Stephanie. 2014. 'Gender and Global Value Chains: Challenges of Economic and Social Upgrading in Agri-Food'. In EUI Working Papers. Vol. 96. Robert Shuman Centre for Advanced Studies. . 2019. Capturing the Gains: Gender and Work in Global Value Chains. Cambridge: Cambrdige University Press.

Beneria, L. 2007. 'Gender and the Social Construction of Markets'. In The Feminist Economics of Trade, edited by I. Van Staveren, D. Elson, C. Grown, and N. Cagatay, 13-32. London: Routledge.

Better Work. 2016. 'Better Work: Progress and Potential, Findings from an Independent Impact Assessment'. Geneva: ILO/IFC Better Work Programme.

Bourke-Martignoni, Joanna, and Elizabeth Umlas. 2018. 'Gender-Responsive Due Diligence for Business Actors: Human Rights-Based Approaches'. 12. Academy Briefing. Geneva Academy. https://www.genevaacademy.ch/joomlatools-files/docman-files/Academy\%20Briefing\%2012interactif-V3.pdf.

BSR. 2018a. 'Gender Sensitive Social Auditing'. Business for Social Responsibility. . 2018b. 'Gender Sensitive Social Auditing'. Business for Social Responsibility.

Burns, D. 2007. Systematic Action Research: A Strategy for Whole System Change. Bristol: Policy Press.

CHRB. 2018. 'Corporate Human Rights Benchmark 2018 Key Findings'. https://www.corporatebenchmark.org/sites/default/files/documents/CHRBKey Findings2018.pdf.

Distelhorst, G., and R. Locke. forthcoming. 'Does Compliance Pay? Social Standards and Firm-Level Trade'. American Journal of Political Science. https://papers.ssrn.com/sol3/papers.cfm?abstract_id=2885455.

Dolan, C., M. Opondo, and S. Smith. 2004. 'Gender, Rights and Participation in the Kenya Cut Flower Industry’. Natural Resources Institute, University of Greenwich.

Eden, C., and C. Huxham. 1996. 'Action Research for Management Research'. British Journal of Management 7: 75-86.

Elson, D. 1999. 'Labor Markets as Gendered Institutions: Equality, Efficiency and Empowerment Issues'. World Development 27 (3): 611-27.

Elson, D., and R. Pearson. 1981. 'Nimble Fingers Make Cheap Workers, An Analysis of Women's Employment in Third World Export Manufacturing'. Feminist Review Spring: 87-107.

ETI. 2015. 'Auditing Working Conditions: Breaking through the Conspiracy of Silence.' http://www.ethicaltrade.org/issues/auditing-working-conditions. . 2018. 'Base Code Gudiance: Gender Equality (B) - Gender and Human Rights Due Diligence'. London: Ethical Trading Initative.

Evers, B., F. Amoding, and A. Krishnan. 2014. 'Social and Economic Upgrading in Floriculture Global Value Chains: Flowers and Cuttings GVCs in Uganda'. Capturing the Gains Working Paper. Manchester: University of Manchester.

Fair Wear. 2018. 'Breaking the Silence: The FWF Violence and Harassment Prevention Programme'. Amsterdam: Fair Wear Foundation.

Fairwear. 2018. 'Breaking the Silence: The FWF Violance and Harassment Prevention Programme'. Amsterdam: Fairware Foundation.

Gereffi, G. 2005. The New Offshoring of Jobs and Global Development. ILO Social Policy Lectures. Geneva: International Labour Organization. 
Gereffi, G., J. Humphrey, and T. Sturgeon. 2005a. 'The Governance of Global Value Chains'. Review of International Political Economy 12 (1): 78-104.

2005b. 'The Governance of Global Value Chains'. Review of International Political Economy 12 (1): 78-104.

Gibbon, P., and S. Ponte. 2005. Trading Down: Africa, Value Chains and the Global Economy. Philadelphia: Temple University Press.

Goetz, A.M. (ed.). 1997. Getting Institutions Right for Women in Development. London: Zed Press.

Hendrickx, Frank, Axel Marx, Glenn Rayp, and Jan Wouters. 2016. 'The Architecture of Global Labour Governance'. International Labour Review 155 (3): 339-55. https://doi.org/10.1111/j.1564-913X.2015.00039.x.

Henson, S., and J. Humphrey. 2010. 'Understanding the Complexities of Private Standards in Global Agri-Food Chains as They Impact Developing Countries'. Journal of Development Studies 46 (9): 1628-46.

Horner, R. 2017. 'Beyond Facilitator? Sate Roles in Global Value Chains and Global Production Networks'. Geography Compass 11 (2): 1-13.

Hoskyns, C, and S. Rai. 2007. 'Recasting the Global Political Economy: Counting Women's Unpaid Work'. New Political Economy 12 (3): 297-317.

Hoskyns, Catherine, and Shirin M. Rai. 2007. 'Recasting the Global Political Economy: Counting Women's Unpaid Work'. New Political Economy 12 (3): 297-317. https://doi.org/10.1080/13563460701485268.

Human Rights Council. 2011. Guiding Principles on Business and Human Rights: Implementing the United Nations "Protect, Respect and Remedy" Framework. . 2019. Gender Dimensions of the Guiding Principles on Business and Human Rights.

IFC. 2013. 'Investing in Women's Employment: Good for Business, Good for Development.'

ILO. 2015. 'World Employment and Social Outlook'. . 2016. 'Decent Work in Global Supply Chains: General Discussion for the 105th Session of the International Labour Conference (2016)'. Geneva: International Labour Organisation. . 2017. 'Purchasing Practices and Working Conditions in Global Supply Chains: Global Survey Results'. INWORK Issue Brief No. 10. Geneva: International Labour Office.

Islam, Muhammad Azizul, Craig Deegan, and Rob Gray. 2018. 'Social Compliance Audits and Multinational Corporation Supply Chain: Evidence from a Study of the Rituals of Social Audits'. Accounting and Business Research 48 (2): 190-224.

Islam, Muhammad Azizul, and Kenneth James McPhail. 2011. 'Regulating for Corporate Human Rights Abuses: The Emergence of Corporate Reporting on the ILO's Human Rights Standards within the Global Garment Manufacturing and Retail Industry'. Critical Perspectives on Accounting 22 (8): 790-810.

ITUC. 2018. 'Campaign Toolkit: Stop Gender-Based Violence at Work. Support an ILO Convention.' Brussels: Internattional Trade Union Confederation. https://www.ituc-csi.org/campaign-toolkit-stop-gender-based.

Jenkins, R., R. Pearson, and G. Seyfang, eds. 2002. Corporate Responsibility and Labour Rights: Codes of Conduct in the Global Economy. London: Earthscan.

KHRC. 2012. "'Wilting in Blook" The Irony of Women Labour Rights in the CutFlower Sector in Kenya'. Nairobi: Kenya Human Rights Commission. 
Kinney, William R. 1988. 'Discussant's Response to Why the Auditing Standards on Internal Control Needed to Be Replaced.' In , 55-60.

LeBaron, Genevieve, and Jane Lister. 2015. 'Benchmarking Global Supply Chains: The Power of the "Ethical Audit" Regime'. Review of International Studies 41 (5): 905-24. https://doi.org/10.1017/S0260210515000388.

Locke, R. 2013. The Promise and Limits of Private Power: Promoting Labor Standards in a Global Economy. New York: Cambridge University Press.

Marx, Axel, and Jan Wouters. 2016. 'Redesigning Enforcement in Private Labour Regulation: Will It Work?' International Labour Review 155 (3): 435-59.

Mayer, F., and A. Posthuma. 2012. 'Governance in a Value Chain World'. Capturing the Bains Briefing. University of Manchester.

Muchlinski, Peter. 2003. 'Human Rights, Social Responsibility and the Regulation of International Business: The Development of International Standards by Intergovernmental Organisations'. Non-State Actors International Law 3 (1): $123-52$.

Nadvi, K. 2008. 'Global Standards, Global Governance and the Organization of Global Value Chains'. Journal of Economic Geography 8: 323-43.

Neilson, J., and B. Pritchard. 2009. Value Chain Struggles: Institutions and Governance in Plantation Districts of South India. Wiley-Blackwell.

Oxfam. 2018. 'Ripe for Change: Ending Human Suffering in Supermarket Supply Chains'. Oxford: Oxfam Internaitonal. https://policypractice.oxfam.org.uk/publications/ripe-for-change-ending-human-sufferingin-supermarket-supply-chains-620418.

Oxfam/IPL. 2013. 'Exploring the Links between International Business and Poverty Reduction, Bouquets and Beans from Kenya'.

Palpacuer, Florence. 2008. 'Bringing the Social Context Back in: Governance and Wealth Distribution in Global Commodity Chains'. Economy and Society 37 (3).

Pearson, R. 1998. “"Nimble Fingers" Revisited: Reflections on Women and Third World Industrialisation in the Latee Twentieth Century'. In Feminist Visions of Development, edited by C. Jackson and R Pearson, 171-88. London: Routledge.

Pearson, R, and G. Seyfang. 2001. 'New Hope or False Dawn? Voluntary Codes of Conduct, Labour Regulations and Social Policy in a Globalising World'. Global Social Policy 1 (1): 49-78.

Phillips, N., F. Mayer, and A. Posthuma. 2017. 'The Political Economy of Governance in a "Global Value Chain World"'. New Political Economy 22 (2): 129-33.

Ponte, S., and T. Sturgeon. 2014. 'Explaining Governance in Global Value Chains: A Modular Theory-Building Effort'. Review of International Political Economy 21 (1): 195-223.

Posthuma, Anne, and Arianna Rossi. 2017. 'Coordinated Governance in Global Value Chains: Supranational Dynamics and the Role of the International Labour Organization'. New Political Economy 22 (2): 186-202. https://doiorg.manchester.idm.oclc.org/10.1080/13563467.2016.1273342.

Ramasastry, Anita. 2015. 'Corporate Social Responsibility Versus Business and Human Rights: Bridging the Gap Between Responsibility and Accountability'. Journal of Human Rights 14 (2): 237-59. http://dx.doi.org/10.1080/14754835.2015.1037953. 
Ruggie, John. 2008. 'Protect, Respect and Remedy: A Framework for Business and Human Rights'. Innovations: Technology, Governance, Globalization 3 (2): 189-212.

2013. 'Progress in Corporate Accountability'. IHRB (blog). 2013. https://www.ihrb.org/focus-areas/benchmarking/commentary-progresscorporate-accountability. . 2014. 'Global Governance and "New Governance Theory": Lessons from Business and Human Rights'. Global Governance 20 (1): 5-17. . 2017. 'The Social Construction of the UN Guiding Principles on Business \& Human Rights'. https://papers.ssrn.com/sol3/papers.cfm?abstract_id=2984901. . 2018. 'Multinationals as Global Institution: Power, Authority and Relative Autonomy'. Regulation \& Governance 12 (3): 317-33.

Said-Allsopp, M., and A. Tallontire. 2015. 'Pathways to Empowerment? Dynamics of Women's Participation in Global Value Chains'. Journal of Cleaner Production 107: 114-21.

Scott, L. 2017. 'Private Sector Engagement with Women's Economic Empowerment: Lessons Learned from Years of Practice'. Oxford: Said Business School.

Sengenberger, W. 2002. Globalisation and Social Progress: The Role and Impact of International Labour Standards. Bonn: Fredrick Ebert Stiftung.

Sinkovics, Noemi, Samia Ferdous Hoque, and Rudolf R. Sinkovics. 2016. 'Rana Plaza Collapse Aftermath: Are CSR Compliance and Auditing Pressures Effective?' Accounting, Auditing \& Accountability Journal 29 (4): 617-49.

Smith, A. 2015. 'The State, Institutional Frameworks and the Dynamics of Capital in Global Production Networks'. Progress in Human Geography 39 (3): 290315.

Stewart, A. 2011. Gender, Law and Justice in a Global Market. Cambridge: Cambridge University Press.

Terwindt, C., and A. Armstrong. 2018. 'Oversight and Accountability in the Social Auditing Industry - the Role of Social Compliance Initiatives'. International Labour Review. https://doi.org/10.1111/ilr.12085.

Waterman, P., and J. Wills, eds. 2001. Place, Space and the New Labour Internationalisms. Oxford: Blackwell. 